\title{
Trajectories of regional cooperation: a comparative analysis
}

\author{
Diana Panke ${ }^{1} \cdot$ Anna Starkmann ${ }^{1}$
}

Accepted: 27 October 2020 / Published online: 18 November 2020

(c) The Author(s) 2020

\begin{abstract}
Cooperation between states takes place in International Organizations (IOs) and Regional Organizations (ROs). Since we know more about the evolution of cooperation in IOs than ROs, this paper examines trajectories of regional cooperation. Based on a novel dataset, it provides a descriptive analysis of how all 76 ROs developed over time. This reveals that regional cooperation evolved in two waves with respect to RO size as well as the policy areas of cooperation. The paper adopts an explorative approach to examine these patterns. This reveals that ROs with regional courts and ROs which adopt a model of dynamic change are more likely to broaden their policy scopes. In addition, during the Cold War, ROs with initially broad policy scopes were less likely to obtain additional competencies, while after 1990 ROs were more likely to broaden their policy scopes when they are large in size, when their members are economically strong and when majority decisions are possible in their day-to-day operation.
\end{abstract}

Keywords Regional cooperation · Regional organizations · Policy competencies · Membership · Explorative study

\footnotetext{
This paper is part of a research project "Towards an Increasing Regionalization of International Politics? Comparing the Development of External and Internal Competencies of Regional Organizations over Time" funded by the Fritz-Thyssen-Foundation (Az.10.16.1.012IB). Earlier versions of this paper have been presented at various conferences and workshops and we are grateful for the constructive comments we received from Cassandra V. Emmons, Anja Jetschke, Tobias Lenz, Johannes Muntschick, Nina Reiners, and Frederik Söderbaum. We would like to thank Ikram Ali, Lea Gerhard, Clara Hirschmann, Laura Lepsy, Laura Maghetiu, Paul Meiners, Leonardo Rey, Benjamin Schäfer, Edward Vaughan, Philipp Wagenhals, and Ivan Zolotarevskii for valuable assistance in researching sources, coding documents, supporting the databank management, literature research, and proofreading
}

Diana Panke

Diana.Panke@politik.uni-freiburg.de

http://portal.uni-freiburg.de/politik/professuren/governance

Anna Starkmann

Anna.Starkmann@politik.uni-freiburg.de

1 Professur Für Governance in Mehrebenensystemen, Seminar für Wissenschaftliche Politik, Albert-Ludwigs-Universität Freiburg, Belfortstr. 20, 79085 Freiburg, Germany 


\section{Introduction}

International organizations (IOs) are institutionalized arenas for cooperation between at least three states and come in different forms and shapes. Some are potentially global in character and others are regional. Unlike global IOs, regional organizations (ROs) have limited instead of potentially global state membership, and the membership criteria are related to the geographical location of states (Börzel and Risse 2016; Hooghe et al. 2017). While we know a lot about the development and expansion of global IOs (e.g. Barnett and Finnemore 2004; Hurd 2011; Archer 2014; Gray 2018), trajectories of RO developments are less often in the focus of International Relations scholarship. This is surprising since states often cooperate in and through ROs (Panke 2020). Although there is a growing literature comparing ROs (Haftel and Hofmann 2017; Börzel and Risse 2016; Panke et al. 2020), we do not know much about how ROs evolved concerning two central elements: RO size and policy scope. The latter is important as it forms a precondition for which policies ROs can pass and what activities they can engage in their day-to-day operation. The former matters as it is the member states of ROs who participate in deciding about the content of RO policies and activities, thereby influencing who benefits from them.

This paper takes stock of the development of regional cooperation over time and examines two research questions: How many ROs were created over time and how did they evolve with respect to their size? Which differences and similarities can be observed with respect to development of formal RO policy competencies over time and between ROs? We also adopt an exploratory approach and discuss possible factors behind the observed patterns.

Answering the first question, a descriptive analysis of the Regional Organization Competencies database (ROCO) of all 76 ROs from 1945 to 2015 reveals interesting insights into patterns of regional cooperation over time. ${ }^{1}$ First, regional cooperation takes place all over the globe. As of 2015, there were 20 ROs in Africa, 16 in the Americas, 22 in Asia, and 13 in Europe. Second, the numbers of ROs have increased from two in 1945 to 71 in 2015. The longitudinal analysis shows that there are two different waves of regional cooperation, one after the end of WWII and one after the end of the Cold War. Over time, the size of ROs also increased on average, indicating an increased attractiveness of ROs as outlets for cooperation.

With regard to the second question, the analysis shows that RO policy scopes became broader over time as the number of different formal policy competencies as laid out in RO primary law (e.g. Treaties, Annexes) increased. While the average RO covered 13.5 different policy competencies in 1950, the number has increased to 53.2 in 2015. The broadening of RO policy scopes reflects two waves of regional cooperation: after the end of WWII, RO policy competencies increased incrementally, while after the end of the Cold War there is a much steeper increase in the policy scope of ROs. Yet, the analysis shows that not all

\footnotetext{
${ }^{1}$ To access the dataset: https://dataverse.harvard.edu/dataset.xhtml?persistentId=doi:10.7910/DVN/ UBXZHC
} 
ROs contribute to this pattern equally, as they differ considerably in the number of policy competencies as well as the broadening of policy scopes over time. In order to further shed light on this pattern, we adopt an explorative approach. Based on quantitative methods, we examine factors possibly contributing to differences in the trajectories of RO development over time. This reveals that RO policy competencies get broadened, if regional courts are present. In addition, the analysis suggests that some ROs are very dynamic in character. Hence, the less time has passed since the last Treaty change, the more likely ROs are to expand their policy scope. Moreover, there are specific factors at play in the development of RO policy scopes prior to and after 1990, reflecting the fact that there are two different waves of regional cooperation. Before the end of the Cold War, ROs with broad policy scopes are less likely to increase the number of policy competencies. After 1990, ROs have a higher likelihood to obtain additional policy competencies, the greater the average economic strength of RO member states, if ROs allow for majority decision-making in the day-to-day operation, and the larger ROs are.

In short, this paper shows that like international organizations, regional organizations proliferated over time. Second, the end of the Cold War marks a turning point in cooperation patterns on the regional and the global level, as the number of newly created organizations increases considerably. Third, while some IOs experience an increase in policy competencies over time as well, these dynamics are more pronounced for ROs. This difference between IOs and ROs is not so much related to differences in how states cooperate on the global as opposed to the regional level, but rather reflects that the former are often task-specific in nature, while the latter tend to be general-purpose organizations (Lenz et al. 2015).

\section{Analysis I: the evolution of ROs and RO size}

ROs are often regarded as suitable arenas for effectively tackling problems of crossborder nature and contributing to the solution of today's global governance challenges since they tend to be smaller than IOs, more homogenous in terms of their member states, and consequently in a better position to agree on common policies and activities (for an overview, c.f. Panke et al. 2018). Thus, studying which ROs exist and how they evolved over time is of high importance. While regional integration scholarship focuses most often on the European Union (EU), ${ }^{2}$ a newer research agenda on comparative regionalism became prominent in the last decades studying ROs from all over the globe and engaging in qualitative comparative studies of different European and non-European ROs (for an overview c.f. Bowles 1997; Hettne

\footnotetext{
${ }^{2}$ While the EU is the most researched regional organization (RO), it is neither the oldest of its kind, nor the largest one. The oldest RO date backs to 1910 when the predecessors of today's Botswana, Lesotho, Namibia, South Africa and Swaziland founded SACU, while SACU can be regarded as the oldest RO, the Organisation for Security and Co-operation in Europe (OSCE) with its 56 member states, followed by the AU which today encompasses 55 members are the largest ROs.
} 
and Söderbaum 1998; Breslin et al. 2013; Sunkel and Inotai 2016; Panke and Stapel 2018). This article contributes to comparative regionalism research. It provides a comparative analysis of how 76 ROs evolved over time with respect to their numbers and discusses how and why they increased in size (this section). Subsequently it examines how as their formal policy competencies developed over time and discusses drivers of these the patterns over time and between ROs (c.f. analysis II section). "Analysis II: formal policy competencies of ROs" section.

We define regional organizations (ROs) as institutionalized forms of cooperation between three or more states concerning more than one narrowly defined issue. Unlike in IOs, state membership is based on geographical criteria in ROs. Applying this definition to the post-WWII period (1945-2015), 76 organizations classify as ROs, when coding legal predecessors and successors, such as the Organization of African Unity (OAU) and the AU, as one organization (for more details see Panke et al 2020). A list of the 76 ROs that are included in our Regional Organization Competencies database (ROCO) is provided in Table 1. The database captures which ROs existed in a given year as well as the number of member states of each $\mathrm{RO}$ in each year for the period of observation (1945-2015). ${ }^{3}$

\section{The number of ROs over time}

Examining the number of ROs in the period of observation, between 1945 and 2015, reveals that regional cooperation started with two existing ROs in 1945, the Southern African Customs Union (SACU) and the League of Arab States (AL), and increased to a total of 71 different ROs in 2015 [some ROs disbanded, e.g. the Warsaw Treaty Organization (WTO)].

Figure 1 illustrates that there are two waves of regional cooperation: in the 1950s and again in the 1990s the number of existing ROs increases considerably. In 1950 there were 6 ROs, namely the Council of Europe, the North Atlantic Treaty Organization, the Organization of American States (OAS), the Pacific Community (PC), the AL, and SADC, and this number increased to a total of 17 ROs in the year 1960. Another stark rise took place after the end of the Cold War, as the number of ROs increased from 37 in 1990 to a total of 59 in 2000, respectively.

Which possible reasons are behind this trend? As the international cooperation literature suggests, globalization and an increased interdependence has rendered unilateral state actions less effective (Keohane and Nye 1977) and brought about an increase in the creation of international organizations (Kratochwil and Ruggie 1986; Barnett and Finnemore 2004; Archer 2014). The same applies to the regional level, on which ROs were increasingly created to address cross-border problems and enhance trade and security (c.f. Fawcett and Hurrell 1995; Börzel 2016; Sunkel and Inotai 2016). In addition to these global trends, with the end of the Cold War, newly independent states increasingly create ROs as well, which contributed to the second wave of regionalism (Fawcett and Hurrell 1995; Mansfield and Milner 1999;

\footnotetext{
${ }^{3}$ Further information on coding decisions is available online, c.f. authors 2019.
}

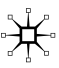


Table 1 ROs in the ROCO database

\begin{tabular}{|c|c|c|}
\hline RO & Full name & Founded \\
\hline $\mathrm{AC}$ & Arctic Council & 1996 \\
\hline ACC & Arab Cooperation Council & 1989 \\
\hline ACD & Asia Cooperation Dialogue & 2001 \\
\hline ACS & Association of Caribbean States & 1994 \\
\hline ACTO & Amazonian Cooperation Treaty Organization & 1995 \\
\hline $\mathrm{AL}$ & League of Arab States & 1945 \\
\hline ALADI & Latin American Integration Association & 1960 \\
\hline ALBA & Bolivarian Alliance for the Peoples of Our Americas & 2004 \\
\hline AMU & Arab Maghreb Union & 1989 \\
\hline ANDEAN & Andean Community & 1969 \\
\hline APEC & Asia-Pacific Economic Cooperation & 1989 \\
\hline ASEAN & Association of Southeast Asian Nations & 1967 \\
\hline $\mathrm{AU}$ & African Union & 1963 \\
\hline BEU & Benelux Economic Union & 1958 \\
\hline BIMSTEC & $\begin{array}{l}\text { Bay of Bengal Initiative for Multi-Sectoral Technical and Economic Coopera- } \\
\text { tion }\end{array}$ & 1997 \\
\hline BSEC & Black Sea Economic Cooperation & 1992 \\
\hline CACM & Central American Common Market & 1960 \\
\hline CAEU & Council of Arab Economic Unity & 1957 \\
\hline CALC & Latin American and Caribbean Summit on Integration and Development & 2008 \\
\hline CAREC & Central Asia Regional Economic Cooperation & 2006 \\
\hline CARICOM & Caribbean Community & 1965 \\
\hline CBSS & Council of the Baltic Sea States & 1992 \\
\hline CCTS & Cooperation Council of Turkic Speaking States & 2009 \\
\hline $\mathrm{CE}$ & Conseil de l'Entente & 1959 \\
\hline CEEAC & Communauté Economique des États de l'Afrique Centrale & 1983 \\
\hline CEFTA & Cental European Free Trade Agreement & 1992 \\
\hline CELAC & Community of Latin American and Caribbean States & 2011 \\
\hline CEMAC & Communauté économique et monétaire de l’Afrique centrale & 1991 \\
\hline CENSAD & Community of Sahel-Saharan States & 1998 \\
\hline CEPGL & Economic Community of the Great Lakes Countries & 1976 \\
\hline CIS & Commonwealth of Independent States & 1991 \\
\hline $\mathrm{CoE}$ & Council of Europe & 1949 \\
\hline COMESA & Common Market for Eastern and Southern Africa & 1993 \\
\hline CSTO & Collective Security Treaty (Organization) & 1992 \\
\hline EAC & East African Community & 1999 \\
\hline EAEU & Eurasian Economic Union & 2000 \\
\hline $\mathrm{ECO}$ & Economic Cooperation Organization & 1985 \\
\hline ECOWAS & Economic Community of West African States & 1975 \\
\hline EEA & European Economic Area & 1992 \\
\hline EFTA & European Free Trade Association & 1960 \\
\hline $\mathrm{EU}$ & European Union & 1951 \\
\hline G5S & G5 du Sahel & 2014 \\
\hline
\end{tabular}


Table 1 (continued)

\begin{tabular}{|c|c|c|}
\hline RO & Full name & Founded \\
\hline GCC & Gulf Cooperation Council & 1981 \\
\hline GGC & Gulf of Guinea Commission & 2001 \\
\hline GUAM & Organization for Democracy and Economic Development & 1997 \\
\hline ICGLR & International Conference on the Great Lakes Region & 2004 \\
\hline IGAD & Intergovernmental Authority on Development & 1986 \\
\hline IOC & Indian Ocean Commission & 1984 \\
\hline IORA & Indian Ocean Rim Association & 1997 \\
\hline $\mathrm{LCBC}$ & Lake Chad Basin Commission & 1964 \\
\hline MERCOSUR & Mercado Commun del Sur & 1994 \\
\hline MGC & Mekong-Ganga Cooperation & 2000 \\
\hline MRC & Mekong River Commission & 1995 \\
\hline MRU & Manu River Union & 1973 \\
\hline MSG & Melanesian Spearhead Group & 2007 \\
\hline NAFTA & North American Free Trade Organization & 1994 \\
\hline NATO & North Atlantic Treaty Organization & 1949 \\
\hline $\mathrm{NC}$ & Nordic Council & 1952 \\
\hline OAS & Organization of American States & 1948 \\
\hline ODECA & Organization of Central American States & 1951 \\
\hline OECS & Organisation of Eastern Caribbean States & 1981 \\
\hline OSCE & Organisation for Security and Co-operation in Europe & 1975 \\
\hline PA & Pacific Alliance & 2012 \\
\hline PIF & Pacific Islands Forum & 1971 \\
\hline SAARC & South Asian Association for Regional Cooperation & 1985 \\
\hline SACU & Southern African Customs Union & 1945 \\
\hline SADC & Southern African Development Community & 1980 \\
\hline $\mathrm{SCO}$ & Shanghai Cooperation Organization & 2001 \\
\hline SEATO & Southeast Asia Treaty Organization & 1954 \\
\hline SELA & Latin American Economic System & 1975 \\
\hline SICA & Central American Integration System & 1991 \\
\hline SPC & Pacific Community & 1947 \\
\hline SPECA & UN Special Program for the Economies of Central Asia & 1998 \\
\hline UEMOA & West African Economic and Monetary Union & 1994 \\
\hline UNASUR & Union of South American Nations & 2008 \\
\hline WTO & Warsaw Treaty Organisation & 1955 \\
\hline
\end{tabular}

Söderbaum 2004; Acharya and Johnston 2007; Börzel et al. 2012; Börzel and Risse 2016). 


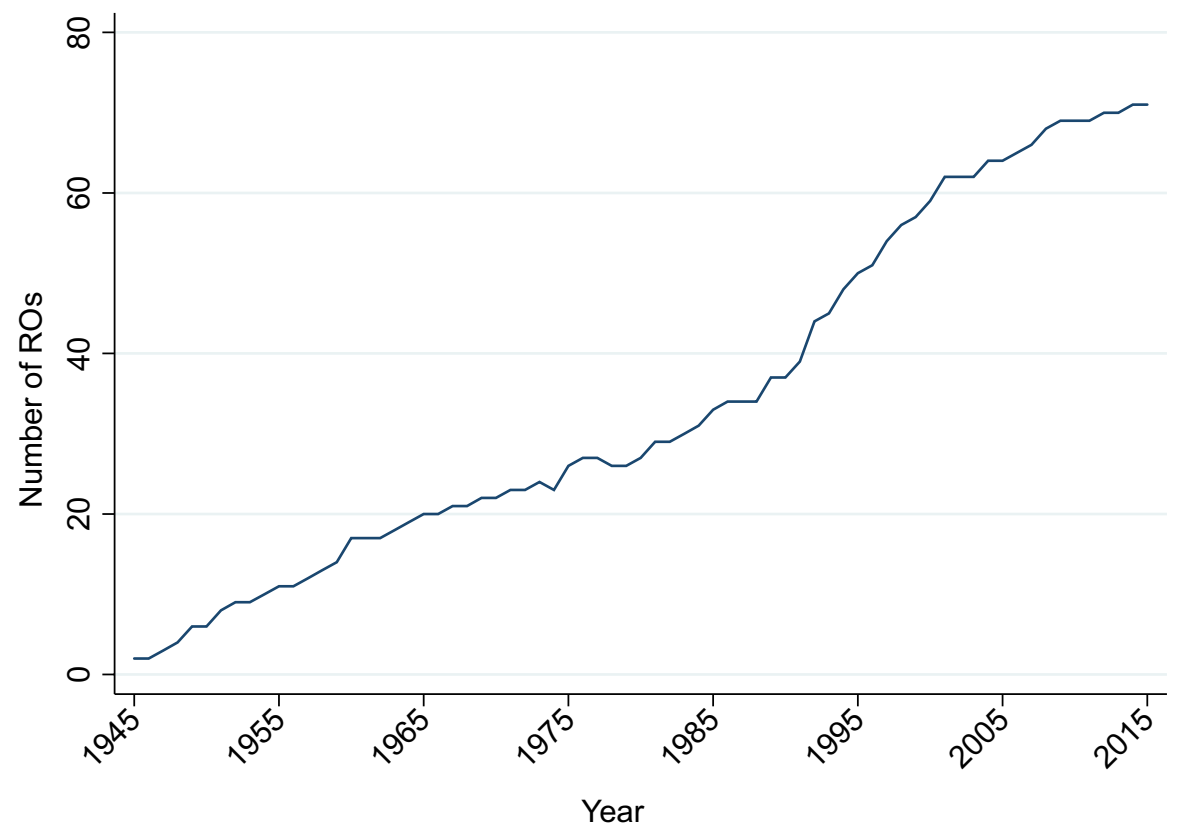

Fig. 1 Existing ROs 1945-2015

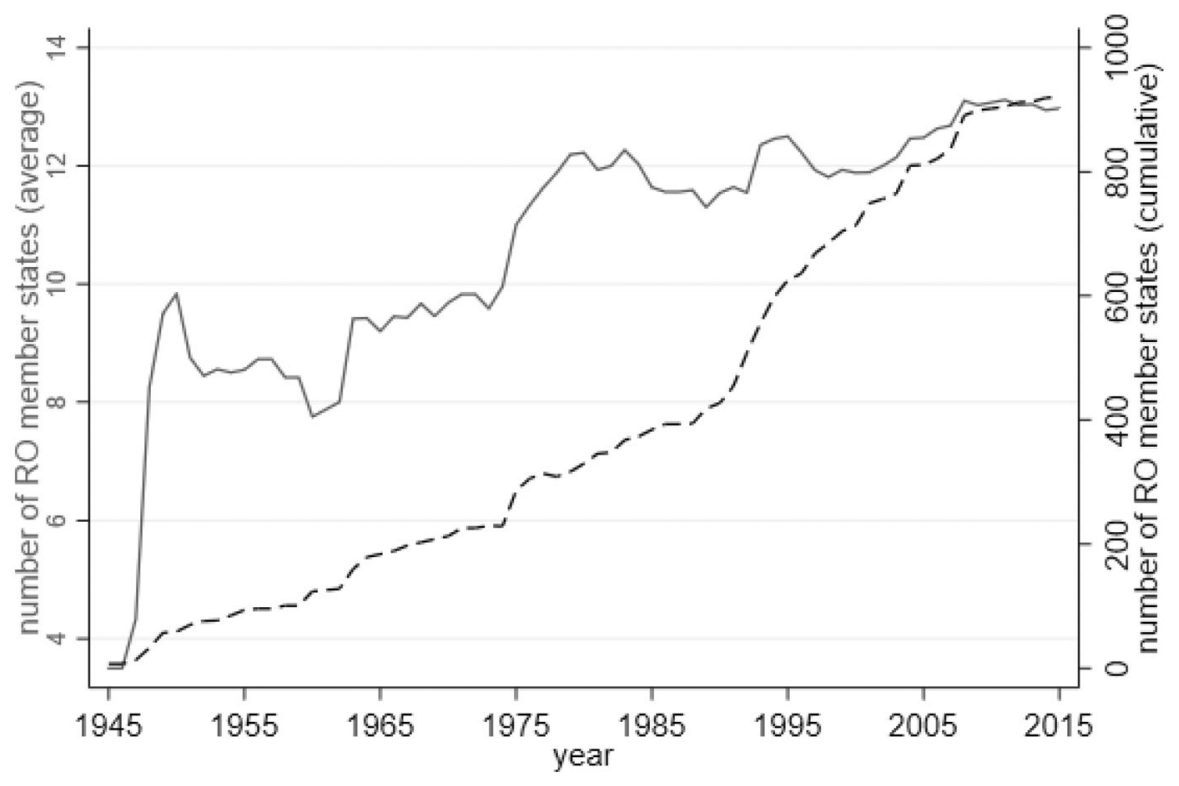

average $\mathrm{RO}$ size $\quad$ - - - - - cumulative $\mathrm{RO}$ size

Fig. 2 RO size over time 


\section{The size of ROs over time}

Not only the number of ROs changed over time, but they also grew in size, defined as the number of member states (c.f. Fig. 2). On average, a RO had about 8 members in 1960, which increased to about 10 in 1970, to 11 in 1990 and stabilized with about 12 member states in 2015. By 2015, the largest RO is the African Union with 53 members, while the smallest ROs are Benelux Economic Union (BEU), Economic Community of the Great Lakes Countries (CEPGL), and the North American Free Trade Agreement (NAFTA) with three member states only.

These dynamics are also reflected in the average number of ROs, a state has joined. In 1945 a state was member in 0.1 ROs, which increased to 1.1 memberships in 1955 , 1.4 in 1965, 1.9 in 1975, 2.3 in 1985, 3.3 in 1995, 4.2 in 2005 and 4.8 in 2015.

Today, states cooperate in ROs in all regions of the world, and apart from Israel, North Korea and Timor-Leste, all countries have at least joined one RO. Thus, Fig. 2 illustrates that the cumulative number of member states increased steadily up until the end of the Cold War and sharply afterwards.

Why do ROs increase in size over time? Most likely, three factors contribute to the observed pattern. First, the enlargement of ROs reflects a rise in the number of independent states in the international system since the end of WWII. Second, research suggests that over time states were increasingly willing to engage in regional cooperation as a means to tackle globalization and increasing interdependence (Keohane and Nye 1977; Fawcett and Hurrell 1995; Börzel 2016). In addition, after the end of the Cold War, states that were no longer aligned with one specific block were re-shaping their foreign and regional policies (Mearsheimer 1990; Goldgeier and McFaul 1992; Doyle 1995; Lebow and Risse-Kappen 1995). Thus, states that were formerly either non-existing, neutral, or having had other alignments also started to also engage in regional cooperation.

\section{Analysis II: formal policy competencies of ROs}

Formal competencies are laid down in RO primary law, such as treaties, annexes, and amendments. They are important to study, as they allow RO members to pass common norms or rules or to engage in joint activities on a day-to-day basis. While some treaties might specify to delegate authority to supranational RO actors (such as secretariats or central banks) to act autonomously from the member states along with these formal competencies, mostly, joint activities and rule-making happen on an intergovernmental basis. Irrespective of the procedures by which member states and $\mathrm{RO}$ actors act upon them, formal competencies do not determine RO conduct in a policy field (Acharya 2011), but constitute an important precondition to become active.

The ROCO database provides information on RO formal policy competencies. In order to obtain information on the numbers and substance of policy competencies per RO and year we coded RO primary law, differentiating between eleven broader substantive policy areas, namely agriculture, development, economy and 


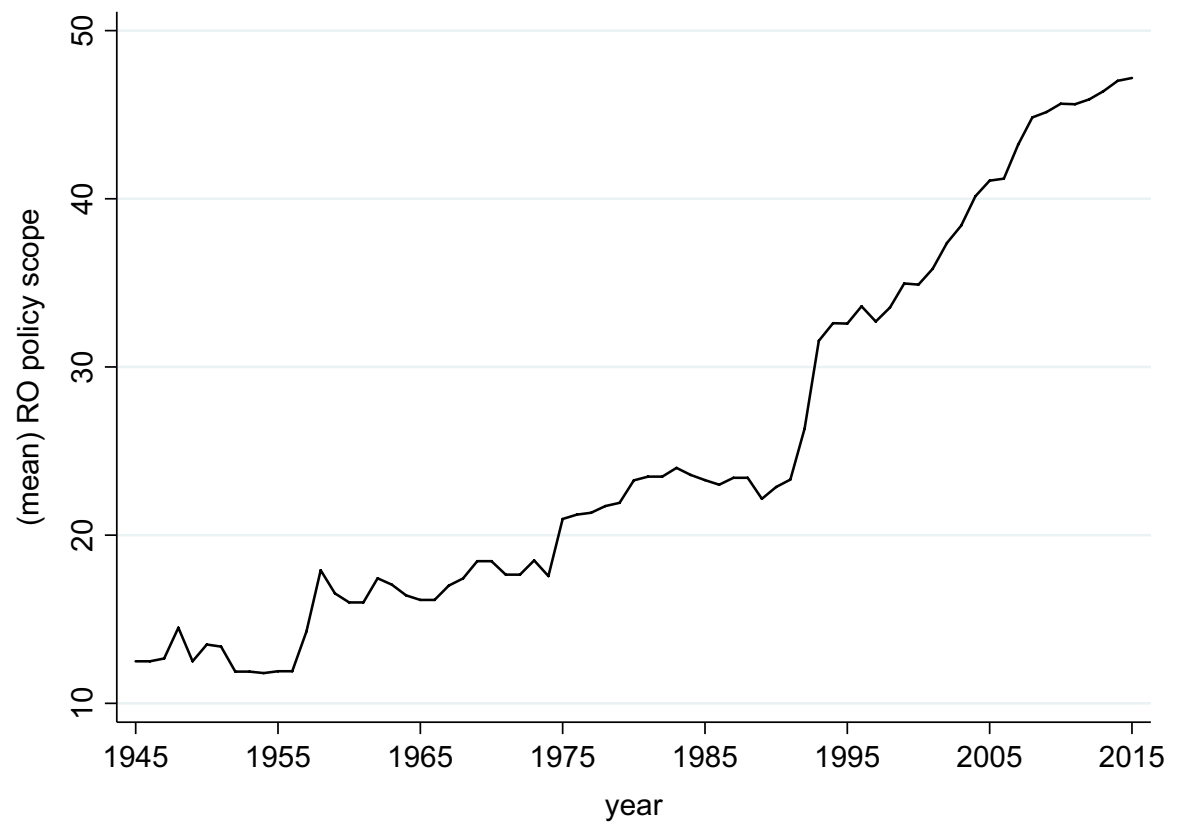

Fig. 3 Mean policy scope over time (1945-2015, 76 ROs)

trade, energy, environment, finance, good governance, health, migration, security and defence, as well as technology, science and infrastructure. Each of these eleven policy areas entails between 14 and 17 subcategories or specific policy competencies (c.f. Table 3, further information on coding is available online). ${ }^{4}$

RO 'policy scope' captures the number of different specific policy competencies an RO possesses in a given year and is a proxy for the emphasis that RO members place on the substantive matters on which they want to cooperate within a RO. The broader the policy scope of an RO, the higher the number of its different specific policy competencies. ${ }^{5}$

\footnotetext{
${ }^{4}$ We furthermore distinguish between an external and an internal policy domain, because they open up the possibility for different RO policies or RO activities (e.g. an RO with the internal competence to combat human trafficking [policy area migration) is able to engage in different activities or policies, then an RO equipped with the external competence to combat human trafficking. While the former activities or policies are directed towards the RO member states themselves, the latter competence can lead to RO activities or policies in the near abroad (i.e. third party states)].

The internal and external dimensions include the same substantive broader policy fields and the same substantive specific policy competencies. Internal and external policy competencies are distinguished by buzzwords defining the context of application. External competencies turn the RO and its member states into actors beyond their borders (indicated by phrases such as "foreign" "global", "third states", etc.), while internal competencies allow ROs and their members to create common rules or act in concert within their borders (indicated by phrases such as "between member states", "contracting parties", etc.). Hence, the raw data entail 11 external and 11 internal policy areas, respectively.

5 The variable 'policy scope' has a minimum of 0 and a maximum of 344 . The minimum value would signify the case that states created an RO without any policy competencies in the beginning at all. The maximum value of a policy scope of 344 would be reached if there were an RO equipped with all 344 different policy competences.
} 


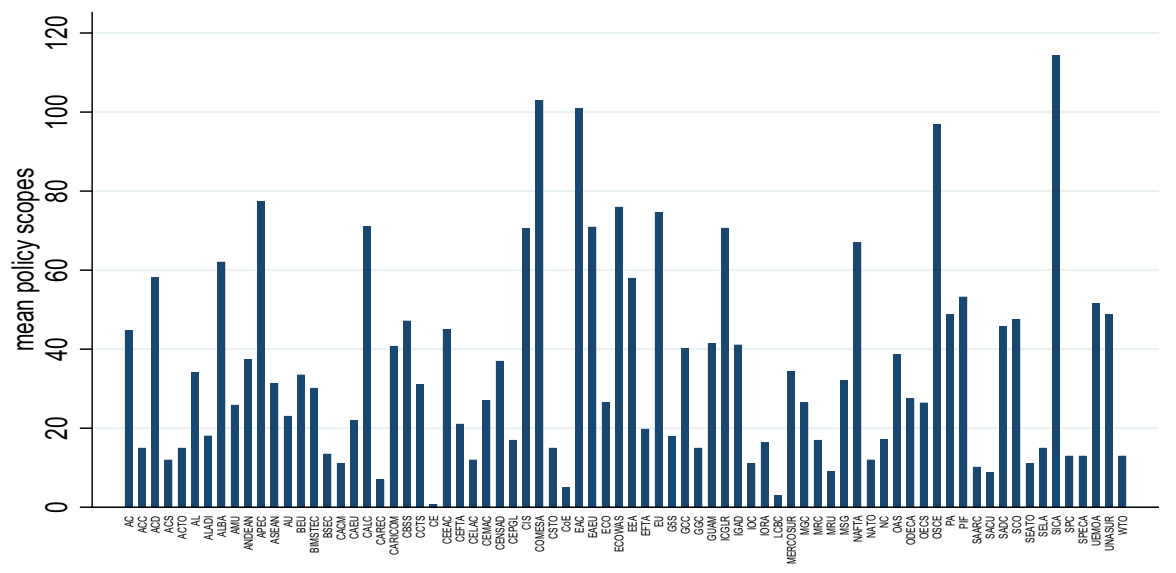

Fig. 4 Mean policy scope between 76 ROs (1945-2015)

Figure 3 depicts the mean policy scope of all ROs over time. This shows that there is a remarkably strong upsurge in the total number of policy competencies after the end of the Cold War. While before 1990, policy competencies were broadened in a slow and incremental fashion, there is a steep increase in RO policy scopes after that. The same pattern emerges if we shift our attention from the mean number of policy competencies to the cumulative policy scope of ROs. In 1960, all ROs together had 256 specific policy competencies. In the following 30 years, ROs gained additional competencies, resulting in a total of 846 competencies in 1990. Remarkably, this number had almost doubled within only five years (1.629 in 1995) and by 2015, the total number of ROs' policy competencies amounts to 3350 .

Why does the policy scope increase over time and especially after 1990? This general temporal trend is in parts due to the creation of new ROs after the end of WWII and the end of the Cold War (see "Analysis I: the evolution of ROs and RO size" section). In addition, several ROs were subject to treaty changes and amendments over time, which also broadened the scope of RO policy competencies as new areas of potential cooperation were put into RO primary law (for the EU c.f. Moravcsik 1998).

While the fact that average RO policy scope increases over time is linked to the increase in the number of ROs, there is considerable variation in the policy scope between ROs, which cannot easily be accounted for. Figure 4 illustrates that the policy scope varies between the 76 ROs.

Several ROs only have a limited number of policy competencies. Examples include the Black Sea Economic Cooperation (BSEC) with a maximum value of 39 and, for the period of its existence, a mean policy scope of 13.5, the Association of Caribbean States (ACS) is equipped with only 12 different policy competencies, the Manu River Union (MRU) only has a policy scope of 9, and the Central Asia Regional Economic Cooperation (CAREC) is furnished with only 7 different policy competencies as of 2015. Conversely, some ROs have considerably more policy competencies. Examples include the EU, which has a maximum policy scope of 148 
(with a mean 74.55), the Central American Integration System (SICA) covers 125 different policy competencies and has a mean policy scope of 114.4, and the East African Community's (EAC) policy scope is 101 in 2015. In between are ROs, such as the African Union (AU) with a total of 51 different policy competencies, the Gulf Cooperation Council (GCC) with a policy scope of 54, or Association of Southeast Asian Nations (ASEAN) with 57 different competencies.

Why have ROs evolved differently with respect to their policy scopes? This question poses a puzzle, which is not easily solved. It requires to open up the black box of RO development and investigate which factors might be responsible for why some ROs have a high number of formal policy competencies, whereas the policy scope of other ROs remains limited. We approach this important question in an exploratory manner and discuss the findings in the light of regional cooperation theories subsequently.

To this end, we analyse the change of policy competencies between ROs over time. The dependent variable 'change in policy scope' has methodological advantages over the absolute number of competencies of a RO in a given year. Not all ROs were created at the same time, and ROs that exist for longer periods of time had more chances to obtain policy competencies. In other words: Studying the changes in RO policy scopes over time, rather than the absolute number of policy competencies, has the advantage of controlling for changes that took place prior to a given point in time in certain ROs.

Based on the insights on the two waves of regional cooperation-before and after the end of the Cold War-we adopt different time horizons in our analysis. In order to shed light on temporal specificities in RO policy development, 1959 and 1989 form the baseline years for the early and late period of regional cooperation, respectively. We select 1959 as the first baseline year, because independent variable data are hardly available prior to this point in time (see below) and because the number of ROs is very low before 1959. We select 1989 as the second baseline year, as it marks the end of the Cold War. For each of these years, we capture the number of different policy competencies that an RO has been equipped with until this point in time, and count the number of changes in each of the preceding years. Thus, the dependent variables (DVs) are the change of policy scopes since 1960 per RO and year (DV1) for the early period of regional cooperation, and the change in policy scopes per RO and year since 1990 (DV2) for the late period.

In the early period of regional cooperation (1960-1989), ROs increased their policy scopes on average by 12.92 competencies. Some ROs had no changes between 1960 and 1989, such as the Pacific Community (SPC), or the Warsaw Treaty Organization (WTO). Others underwent considerable policy scope changes since 1959. This includes the Organization for Security Co-operation in Europe (OSCE) with 82 additional policy competencies, the Pacific Islands Forum (PIF) with 53 additional competencies, or the SACU with a policy scope increase of 7 since 1959.

In the late period of regional cooperation (1990-2015), ROs increased their policy scopes on average by 25.14 competencies. Amongst the ROs with the highest increases in policy scopes compared to 1989 are the Asia-Pacific Economic Cooperation (APEC) with 137 additional policy competencies, the Eurasian Economic Union (EEU) 126, or the EU with 87 new policy competencies. In the period 
between 1990 and 2015, some ROs did not obtain additional competencies, such as the Nordic Council (NC) or the Indian Ocean Commission (IOC).

To uncover possible explanations behind this variation in an exploratory manner, we need to select which factors we include in the analysis. In this respect, factors of interest can be divided into genuine RO variables, such as the number of ROs member states, ${ }^{6} \mathrm{RO}$ decision-making rules, ${ }^{7}$ or the presence of a regional court, ${ }^{8}$ and in aggregated RO-level variables based on member state data, such as economic development ${ }^{9}$ and the level of democracy. ${ }^{10}$ In addition, we investigate whether prior policy competencies and years since last RO primary law change impact changes in RO policy scope. ${ }^{11}$ Table 4 provides the descriptive statistics for all variables (delta policy scope starting in 1960; delta policy scope starting in 1990). ${ }^{12}$

The dataset for has a cross-sectional time series structure and RO-years form the unit of analysis. Thus, we estimated general linear models with negative binomial functions and log links and included clustered standard errors in order to take into account that there are repeated observations for each RO. We chose negative binomial models since the dependent variable (change in the number of different policy competencies) is a count variable that only takes discrete, non-negative values (1, 2, 3, 4, etc.) (Long and Freese 2005; Cameron and Trivedi 2013). We lagged the covariates by two years to allow some time for the independent variables to affect policy competencies, as the process of changing RO primary law often takes some time. Due to the very low number of ROs before 1960, the analysis starts in the 1960s instead of 1945. The first regression model covers the observation period 1961-2015.

\footnotetext{
6 The information on the number of member states per RO and year stems from the ROCO database.

7 Information on the existence of majority decision-making rules for day-to-day operation of the RO is taken from the ROCO database. The variable is binary, coded 1 for every year where majority rules exist in all or at least one part of decision-making and 0 when it does not.

8 The variable takes on the value 1 when a regional court is present in an RO in a given year, and 0 if not. This variable is also included in the ROCO dataset.

9 As a proxy for economic strength of ROs, we use the average gross domestic product (GDP) of the member states in a given RO at a given point in time. Data for GDP are taken from the Quality of Government database and measures Real GDP at constant 2011 national prices in million USD. The countrylevel data are aggregated to the RO level by calculating the average across all member states in a given year.

${ }^{10}$ We included the average democracy scores of member states. Democracy levels are operationalized by the aggregated Polity 2 scores of states from the Polity IV dataset (Marshall 2017; Teorell et al. 2018).

11 Prior policy competencies cover the policy scope as of 1959 (for the early period of regional cooperation) and 1989 (for the late period of regional cooperation). 'Years since last change' counts the years passed since RO primary law was last changed and also stems from the ROCO dataset. These variables are not further transformed. While the 'years since last change' variable already captures annual changes, the 'prior policy competencies' variable does not change over time.

12 The first two set of potential explanatory factors are transformed from level variables into delta change variables in order to mirror the nature of the dependent variable, which captures yearly changes instead of annual levels. Thus, we calculated the baseline values for the years 1960 (as the independent variable data was available for all ROs and years from this date onwards) and 1989 for each of the independent variables, respectively, and deduced this value from the level value in order to arrive at the values for yearly changes for each independent variable.
} 
Table 2 Regression analysis

\begin{tabular}{|c|c|c|c|}
\hline & Both periods & $\begin{array}{l}\text { Early period of } \\
\text { regional cooperation }\end{array}$ & $\begin{array}{l}\text { Late period of } \\
\text { regional coopera- } \\
\text { tion }\end{array}$ \\
\hline & Model 1 & Model 2 & Model 3 \\
\hline \multirow[t]{2}{*}{ RO number member states } & $0.029 *$ & 0.035 & $0.046 * * *$ \\
\hline & $(0.012)$ & $(0.032)$ & $(0.014)$ \\
\hline \multirow[t]{2}{*}{ Majority decision-making } & 0.201 & 0.361 & $0.743 * *$ \\
\hline & $(0.167)$ & $(0.339)$ & $(0.262)$ \\
\hline \multirow[t]{2}{*}{ Regional court } & $0.897 * * *$ & $0.867 *$ & $1.210 * * *$ \\
\hline & $(0.159)$ & $(0.370)$ & $(0.283)$ \\
\hline \multirow[t]{2}{*}{ Economic strength } & $0.000 *$ & -0.000 & $0.000 * * *$ \\
\hline & $(0.000)$ & $(0.000)$ & $(0.000)$ \\
\hline \multirow[t]{2}{*}{ Democracy } & $0.036 *$ & 0.055 & 0.022 \\
\hline & $(0.019)$ & $(0.031)$ & $(0.034)$ \\
\hline \multirow[t]{2}{*}{ Spill-over: prior policy competencies } & -0.016 & $-0.055^{* *}$ & 0.005 \\
\hline & $(0.012)$ & $(0.018)$ & $(0.005)$ \\
\hline \multirow[t]{2}{*}{ Spill-over: years since last change } & $-0.043 * * *$ & $-0.074 * * *$ & $-0.078 * * *$ \\
\hline & $(0.009)$ & $(0.020)$ & $(0.008)$ \\
\hline \multirow[t]{2}{*}{ Constant } & $3.062 * * *$ & $2.980 * * *$ & $2.764 * * *$ \\
\hline & $(0.167)$ & $(0.262)$ & (0.209) \\
\hline Observations & 2118 & 681 & 1437 \\
\hline $\mathrm{BIC}$ & $17,270.357$ & 4201.829 & $10,617.365$ \\
\hline LL & -8604.546 & -2074.820 & -5279.601 \\
\hline
\end{tabular}

Clustered standard errors in parentheses with $* p<0.05, * * p<0.01, * * * p<0.001$

In order to account for the different dynamics of the two waves of regional cooperation (see above), we also estimated distinct models for the first wave between 1961 and 1989 (Model 2, Table 2) and a second wave between 1990 and 2015 (Model 3, Table 2). Rather than discussing the periods separately, we compare the findings for the different time periods with one another as this allows for a nuanced picture on trajectories of regional cooperation.

Table 2 reveals that RO size is positively correlated with policy scope changes of ROs, but only significant in the late period (Model 3). After 1990, an increasing RO size increases the probability for broadening their policy scopes. Examples for ROs that grow after the end of the Cold War and obtain more formal policy competencies include the OSCE (at its maximum 56 members and a policy scope of 108) or the EU (28 member states and a policy scope of 148 at its maximum). After the end of the Cold War the number of newly independent states increased, who created and joined ROs in order to further their interests. Hence, member states were important drivers for changes in RO policy competencies, which resonates with intergovernmental and supranational explanations of regional cooperation.

Intergovernmentalism is based on the notion that states are the key actors in regional cooperation processes: without willing states, organizations cannot 
expand and thrive (Moravcsik 1998; Puchala 1999). Similar to other rationalchoice-based international cooperation theories, states are regarded as strategic rational actors that use ROs as a means of achieving their interests (Hoffmann 1956, 1966). A second prominent regional cooperation approach is supranationalism (Christiansen 2002). Supranationalism is based on the presumption that the development of ROs is dependent upon agents of change, which can be governmental in nature, but also supranational (Stone Sweet and Sandholtz 1997, 1998; Weiler 1981). In both theoretical accounts, state actors can detect and formulate demands for changes in RO policy competencies (Pollack 1998; Sandholtz 1998, Stone Sweet and Sandholtz 1998; Hoffmann 1989; Moravcsik 1998). The higher the number of states that are cooperating within one RO, the more diverse are their preferences with respect to which policy competencies an RO should be equipped with and the more likely are RO primary law reforms that add additional competencies. In smaller ROs, by contrast, the number of member states and the number of different policy interests at stake is likely to be more limited, as a consequence of which the policy scope of ROs is less likely to get broadened over time.

Table 2 further shows that RO decision-making rules tend to impact the likelihood for expanding RO policy scopes. Yet, only after 1990 ROs have significant higher probabilities to broaden their policy scopes, if they allow for majority decisions. This finding reflects that some ROs, such as the West African Economic and Monetary Union (UEMOA) already obtained majority decision-making rules in their founding treaty, while most other ROs introduced majority decision-making at a later point in time. For instance, the International Conference on the Great Lakes Region (ICGLR) changes from unanimity into majority voting in 2006 and broadened its policy scope by 17 competencies afterwards. Similarly, the Intergovernmental Authority on Development (IGAD) shifted from unanimity to majority voting in 1996 and increased its policy scope by 10 competencies (to a total of 65 different competencies). In fact, the overall number of ROs with majority rules increases over time, although the relative share of ROs with majority rules is decreasing. ${ }^{13}$

This finding can be interpreted through the lenses of intergovernmentalism. This theory mainly focuses on 'big bangs', such as conferences of the parties (CoP), in which the heads of state and government meet to change the primary law of their RO (Hoffmann 1989; Moravcsik 1998). Yet, they acknowledge that the day-to-day operation of the RO can cast a shadow of the future over treaty negotiations. States as rational actors seek to design the primary law that lay out the rules of the daily operation of an RO in a manner that is beneficial to them (Moravcsik 1998, similar Koremenos et al. 2001). Larger states are not only more influential in the day-to-day operation of ROs, but-according to intergovernmental theory-also more influential in CoPs since their threats of non-cooperative unilateral actions are more credible than similar threats of smaller states that would be worse off on their own (Tallberg 2006). Thus, in ROs in which a high number of actors can block policies in the

\footnotetext{
13 In the 1960-1989 period, $47.6 \%$ of all ROs had obtained majority decision-making rules, compared to only $40.7 \%$ in the period of 1990 to 2015 .
} 
day-to-day operation of the RO (due to unanimity rules), larger states are less likely to push for changing RO treaties and increase the number of policy competencies. Vice versa, the member states should have greater incentives to agree to a higher number of RO policy competencies when they operate on the basis of majority rules in the day-to-day policy cycle, the greater their potential influence and the lower the risk for policy blockages.

Models $1-3$ in Table 2 illustrate that the presence of a regional court significantly increases the propensity for policy scope expansions in a significant manner in all periods of observation. This reflects that several ROs introduced a regional court after some years of their existence and broadened their scopes of policy competencies after the introduction of the court. SADC, for example, created its court in 1992 (Ruppel and Bangamwabo 2008). Afterwards, its policy scope was broadened from 49 different competencies in 1992 to 54 competencies in 2008.

This finding resonates with supranationalism (Christiansen 2002), which takes into account that pushes for increasing RO policy competencies can also come from regional courts (Joerges 2001). In their judgements, regional courts can set legal precedence and point towards demands for future legal change (Stone Sweet 1999, 2000; Stone Sweet et al. 2001). This cannot only impact the day-to-day operation of the RO, but also create or reinforce demands for primary law changes (Stone Sweet and Brunell 1998; Carrubba and Murrah 2005).

Economic strength robustly shows a positive sign and is also significant in Models 1 and 3 in Table 2 . This suggests that in the late period of regional cooperation, a rise in the average economic strength of RO member states increases the probability of RO policy scope expansion. For instance, the Arab League (AL) and the Council of Baltic Sea States (CBSS) both experienced increases of economic strength in the 1990s, and in both ROs the policy competencies were expanded correspondingly. This observation could be linked to intergovernmentalist theory, which expects that economic interests are a driving force of regional cooperation (Moravcsik 1993, 1997). In this vein, economic strength could translate into RO competency expansion because strong states seek to further their interests through ROs. Alternatively, past economic success of states might lead them to equip ROs with additional competencies in order to benefit in the future as well. Through which of these processes economic strength turns into a push-factor for RO competency expansions cannot be investigated in this study, but calls for further qualitative empirical investigation.

By contrast to the first four factors under investigation, the fifth factor is not significant in the post- or the pre-Cold War period. This suggests that democracy of RO member states does not impact RO policy scope expansion.

Table 1 further illustrates that before 1990, the sign for the covariate 'prior policy competencies' is negative and highly significant (Model 2), while it is positive 
and not significant after 1990 (Model 3). This suggests that only in the early period, a broader prior policy scope significantly reduces the likelihood of future primary law changes adding new policy competencies. For instance, the Benelux Economic Union (BEU) had 32 and the Arab League (AL) 28 different policy competencies in 1959 each, and none of these ROs broadened their policy scope before 1990.

This observation resonates with a third approach to regional cooperation, neofunctionalism. Neo-functionalism focuses functional dynamics that make change an attractive option. One of the core concepts in this respect is 'functional spill-over' (Lowi 1963; Haas 1964; Mutimer 1989; Tranholm-Mikkelsen 1991; Malamud and Dri 2013). Functional spill-over processes are at play when cooperation in one policy domain creates not only benefits for RO members, but has negative unintended consequences. In order to tackle negative externalities, ROs need to have formal competencies in related policy areas. On the one hand, one could expect that the broader an RO's policy scope already is, the higher the number of potentially arising negative externalities and the more likely it is that RO policy scopes get broadened in the future. On the other hand, the relationship might be inverse. The more competencies an RO already has, the greater is the likelihood that the RO is already able to cope with potentially arising negative externalities on the basis of its existing competencies. According to this second logic, ROs with more prior policy competencies should be less in need to obtain additional competencies later on. Our empirical analysis suggests, that the second logic is at play.

Finally, the exploratory analysis shows that an increasing amount of time passed since the last change in RO policy competencies significantly reduces the probability that RO policy scopes get broadened in both periods of regionalism under investigation. This might suggest that in some ROs there is a status quo bias of RO members, whereas other ROs are highly dynamic. A status quo orientation in some ROs resonates with the Use-Select-Change-Create (USCC) model by Jupille et all (Jupille, et al. 2013), according to which actors use existing institutional arrangements rather than changing them-or even creating new ones-whenever the status quo is satisfactory.

\section{Conclusions}

States cooperate with one another in a variety of different policy areas and in a variety of different institutional arrangements. While much IR scholarship focuses on IOs, ROs as venues for state cooperation are less often in the centre of attention. This is surprising as ROs are not simply outlets for regional economic cooperation, but can become active in a broad range of different policy areas covering security issues, migration or development, to name but a few. Thus, ROs form an important part of today's global governance architecture and, therefore, deserve (more) attention of IR scholars. 
In order to shed light on ROs as outlets for cooperation beyond the nation-state, this paper uses the ROCO database to illustrate the evolution of regional cooperation, in general, and the development of the policy competencies of $76 \mathrm{ROs}$ in two periods of regional cooperation, in particular. In a first wave of cooperation, ROs broaden their policy scopes in a rather incremental fashion: an average of 24.8 ROs existed between 1945 and 1989, which underwent an average increase of 12.56 policy competencies. ${ }^{14}$ The pace of regional cooperation accelerated in the late period of regional cooperation starting in 1990. Until 2015, ROs increased their policy scope by 25.14 specific competencies on average.

Yet, there is considerable cross-RO variation, which is puzzling. For instance, by 2015 ASEAN's policy scope has reached 57 (an increase of 19 additional competencies compared to 1989), the OAS added 19 policy competencies compared to what they had in 1989 (39 competencies), and the AU's policy scope increased from 11 in 1989 to 51 in 2015, while ANDEAN only gained one additional competency (achieving a policy scope of 39), and the SPC did not deepen its policy competencies at all. Based on an explorative approach, a series of factors behind the different trajectories of RO development were identified. Interestingly, most observations apply either to the early or the late period. There are two exceptions. First, regional courts contribute to the proliferation of RO policy competencies before and after 1990. Thus, when states equip ROs with supranational actors, they further the possibilities of future regional cooperation in new policy areas, as supranational actors can turn into agents pushing for RO policy scope expansion. Second, in none of the periods does the functional need for broadening RO policy competences grow stronger the longer the treaties and other RO primary law have remained unchanged. Thus, regional cooperation within an RO does not follow an even path as it is not the case that an RO undergoes primary law reforms on a regular basis. In addition to these insights, the analysis reveals that in the early phase of regional cooperation (i.e. before 1990), ROs with broad prior policy scopes were less likely to obtain additional policy competencies afterwards. Thus, ROs that states have already equipped with many policy competencies are in a good position to tackle unintended negative side-effects arising during regional cooperation in an RO within the existing legal framework. For the late period, this paper suggests that different dynamics are at play. After 1990, ROs are especially prone to deepen their policy competencies when members can expect more economic benefits, when ROs allow for majority decisions in their day-to-day operation, and when ROs have high numbers of member states. Thus, in the second wave of regional cooperation, larger ROs with higher numbers of member states and ROs with majority-oriented day-to-day decision-making procedures were equipped with more additional policy competencies than their smaller counterparts and ROs with consensus-orientation and a high number of internal veto players.

Although scholars of comparative regionalism have often criticized the EU bias in integration research (Telò 2001; Acharya 2011; Warleigh and Rosamond 2010),

\footnotetext{
14 Some ROs did not change their competencies at all within this timeframe (e.g. BEU or Council of Arab Economic Unity (CAEU), while the OSCE even obtained 82 additional policy competencies.
} 
the EU experience nevertheless provides valuable lessons for other ROs. Our paper suggests that prominent regional cooperation approaches that are most often used to analyse dynamics of integration within the EU (Hull and Rhodes 1977; George 1993; Moravcsik 1993; Lodge 1998; Puchala 1999; Slapin 2008) might also travel to other ROs. This indicates that in addition to distinct regional specificities (Bowles 1997; Hettne and Söderbaum 1998; Breslin, et al. 2013; Sunkel and Inotai 2016) there are also more general mechanisms at play that can account for trajectories of regionalism across the globe and over a long period of time.

Policy competencies are important because they enable ROs to contribute to addressing global problems. However, whether and under what conditions ROs become active on the basis of their policy competencies and produce outputs, outcomes and have impact in the region and beyond is up to future research.

Funding Open Access funding enabled and organized by Projekt DEAL..

Open Access This article is licensed under a Creative Commons Attribution 4.0 International License, which permits use, sharing, adaptation, distribution and reproduction in any medium or format, as long as you give appropriate credit to the original author(s) and the source, provide a link to the Creative Commons licence, and indicate if changes were made. The images or other third party material in this article are included in the article's Creative Commons licence, unless indicated otherwise in a credit line to the material. If material is not included in the article's Creative Commons licence and your intended use is not permitted by statutory regulation or exceeds the permitted use, you will need to obtain permission directly from the copyright holder. To view a copy of this licence, visit http://creativecommons.org/licen ses/by/4.0/.

\section{Appendix}

See Tables 3 and 4 . 


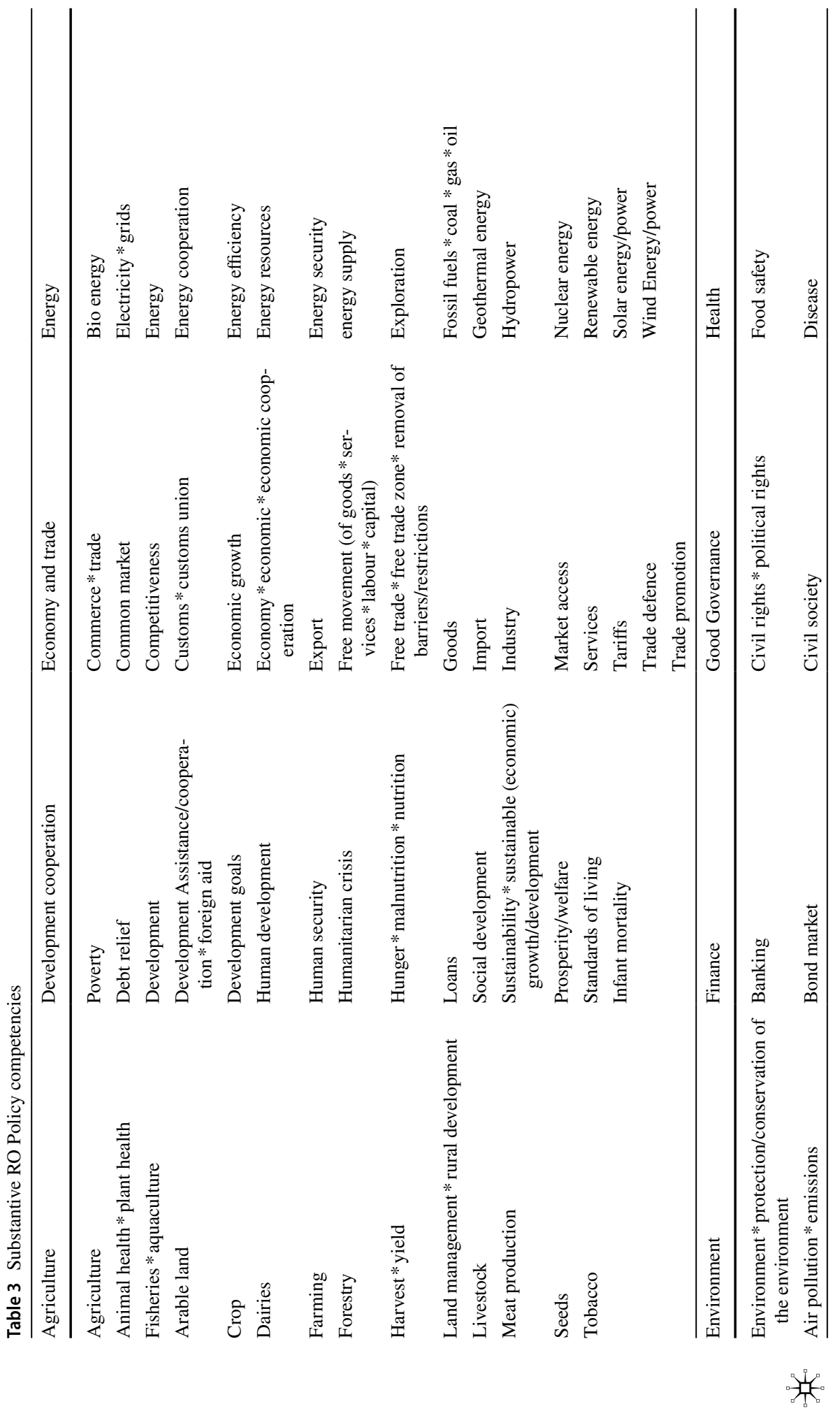




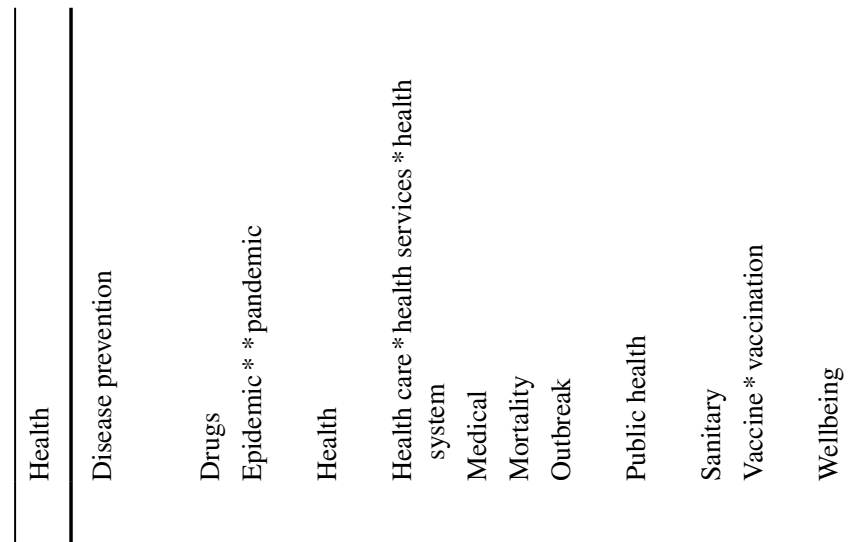

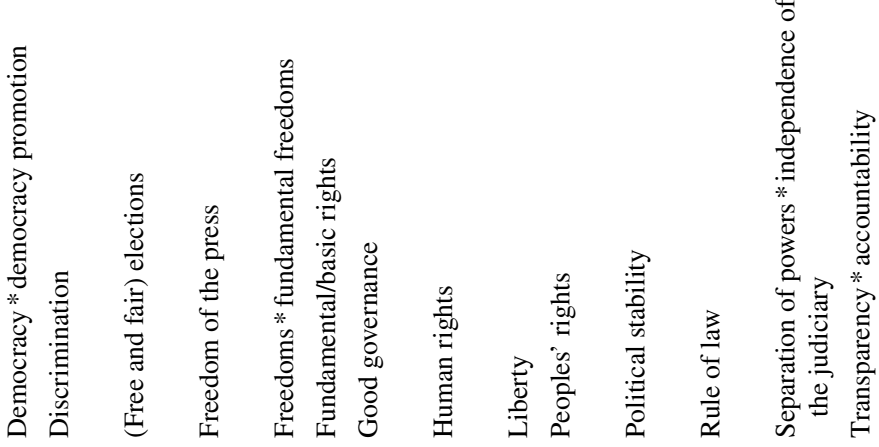

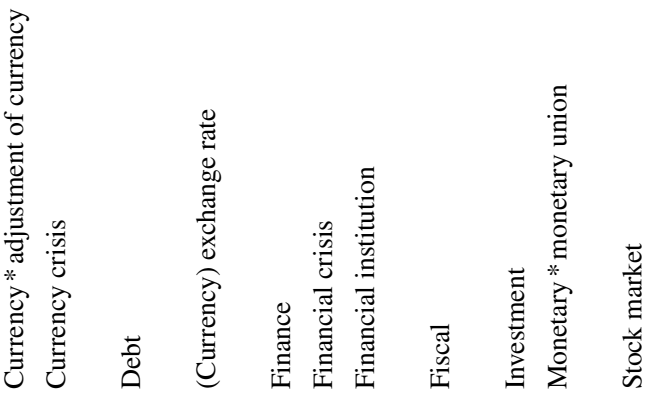

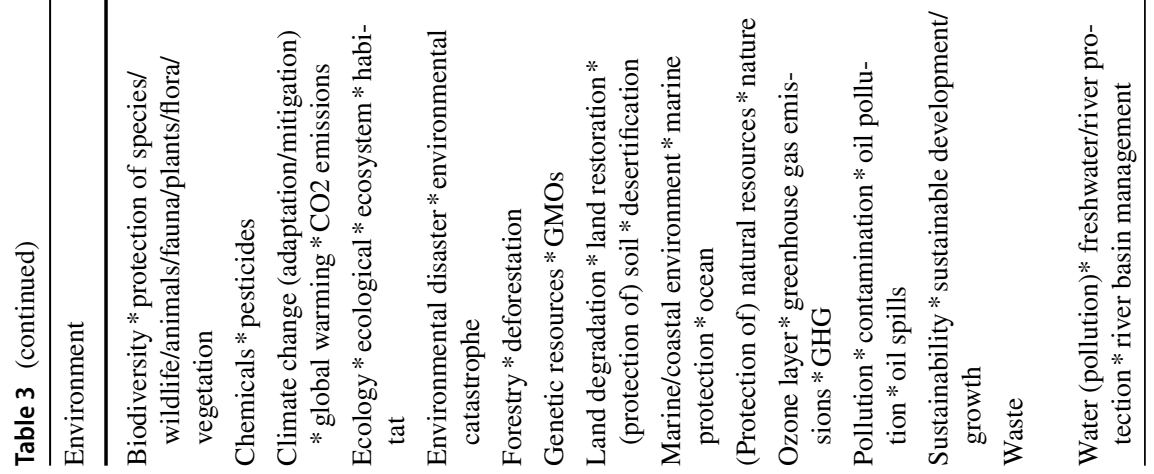

桀 


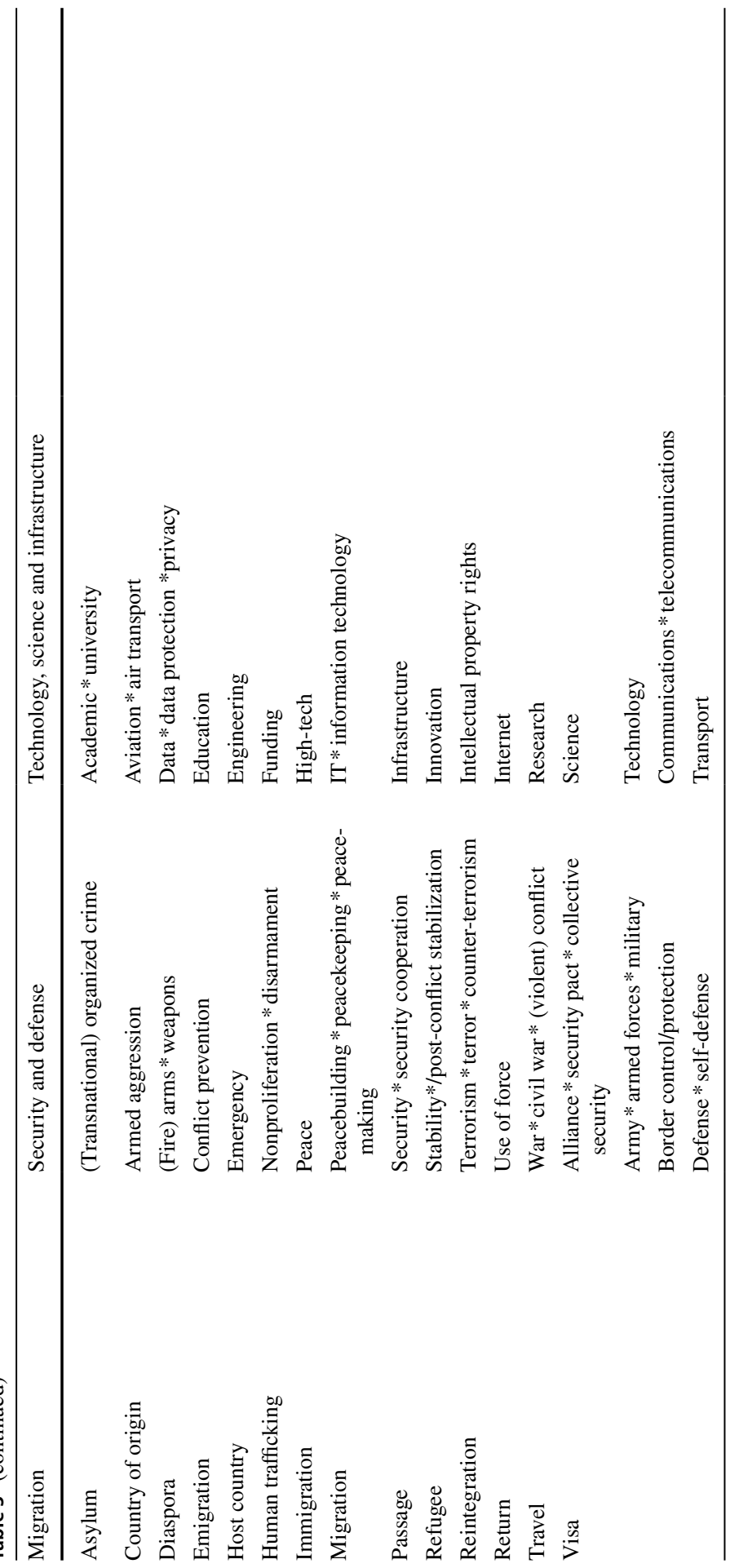


Table 4 Descriptive statistics

\begin{tabular}{lrllll}
\hline Variable & Obs & Mean & Std. Dev & Min & Max \\
\hline $\begin{array}{l}\text { Delta change RO policy competen- } \\
\text { cies-1960 }\end{array}$ & 716 & 12.56564 & 15.60813 & 0 & 82 \\
$\begin{array}{l}\text { Delta change RO policy competen- } \\
\quad \text { cies-1990 }\end{array}$ & 1471 & 25.14208 & 30.52261 & 0 & 137 \\
RO number member states 1960 & & & & & \\
RO number member states 1990 & 2204 & 1.854809 & 6.298648 & -8 & 49 \\
Majority decisions 1960 & 1900 & 4.183158 & 6.706997 & -7 & 33 \\
Majority decisions 1990 & 720 & 0.1555556 & 0.3626854 & 0 & 1 \\
Regional court 1960 & 1471 & 0.1509177 & 0.3580904 & 0 & 1 \\
Regional court 1990 & 720 & 0.0666667 & 0.2496172 & 0 & 1 \\
Average economic strength 1960 & 1470 & 0.1707483 & 0.3764169 & 0 & 1 \\
Average economic strength 1990 & 840 & $144,123.3$ & $264,568.7$ & $-66,740.18$ & $3,518,097$ \\
Democracy 1960 & 1629 & $243,225.1$ & $500,282.5$ & $-264,220.8$ & $3,562,064$ \\
Democracy 1990 & 827 & -0.5639937 & 3.956736 & -9.666667 & 10 \\
Prior policy competencies 1960 & 1604 & 2.234239 & 3.595846 & -6.285714 & 11.91667 \\
Prior policy competencies 1990 & 716 & 7.889665 & 12.63364 & 0 & 47 \\
Years since last change & 1471 & 13.5051 & 17.87705 & 0 & 82 \\
\hline
\end{tabular}

\section{References}

Acharya, Amitav. 2011. Engagement or entrapment? scholarship and policymaking on Asian regionalism. Review of International Studies 13: 12-17.

Acharya, Amitav, and Alastair I. Johnston, eds. 2007. Crafting cooperation. Regional international institutions in comparative perspective. Cambridge: Cambridge University Press.

Archer, Clive. 2014. International organizations. London: Routledge.

Barnett, Michael, and Martha Finnemore. 2004. Rules for the world: International organizations in global politics. Cornell: Cornell University Press.

Börzel, Tanja A. 2016. Theorizing regionalism: Cooperation, integration, and governance. In The Oxford handbook of comparative regionalism, ed. A. Tanja, 41-63. Börzel and Thomas Risse. Oxford: Oxford University Press.

Börzel, Tanja A., Lukas Goltermann, and Kai Striebinger, eds. 2012. Roads to regionalism: Genesis, design, and effects of regional organizations. Aldershot: Ashgate.

Börzel, Tanja A., and Thomas Risse, eds. 2016. The Oxford handbook of comparative regionalism. Oxford: Oxford University Press.

Bowles, Paul. 1997. ASEAN, AFTA and the "new regionalism." Pacific Affairs 70: 219-233.

Breslin, Shaun, Christopher W. Hughes, Nicola Phillips, and Ben Rosamond, eds. 2013. New regionalism in the global political economy: Theories and cases. London: Routledge.

Cameron, A. Colin., and Pravin K. Trivedi. 2013. Regression analysis of count data. Econometric society monographs, 2nd ed. Cambridge: Cambridge University Press.

Carrubba, Clifford J., and Lacey Murrah. 2005. Legal integartion and the use of the preliminary ruling process in the European union. International Organization 59: 399-418.

Christiansen, Thomas. 2002. The role of supranational actors in EU treaty reform. Journal of European Public Policy 9: 33-53.

Doyle, Michael W. 1995. Liberalism and the end of the cold war. In International relations theory and the end of the cold war, ed. R.N. Lebow and T. Risse-Kappen. Columbia: Columbia University Press.

Fawcett, Louise, and Andrew Hurrell, eds. 1995. Regionalism in world politics. Regional organization and international order. Oxford: Oxford University Press. 
George, Stephen. 1993. Intergovernmentalism and supranationalism in the development of the European community. In Frank Pfetsch, ed. Hamburg Münster. Münster: International relations and panEurope. Theoretical approaches and empirical findings. LIT.

Goldgeier, James M., and Michael McFaul. 1992. A tale of two worlds: core and periphery in the postcold war era. International Organization 46: 467-491.

Gray, Julia. 2018. Life, death, or zombie? The vitality of international organizations. International Studies Quarterly 62: 1-13.

Haas, Ernst B. 1964. Beyond the Nation-state. Functionalism and international organization. Stanford: Stanford University Press.

Haftel, Yoram, and Stephanie Hofmann. 2017. Institutional authority and security cooperation within regional economic organizations. Journal of Peace Research 54 (4): 484-498.

Hettne, Björn., and Fredrik Söderbaum. 1998. The new regionalism approach. Politeia 17: 6-21.

Hoffmann, Stanley. 1956. The role of international organization: Limits and possibilities. International Organization 10: 357-372.

Hoffmann, Stanley. 1966. Obstinate or obsolete? The fate of the nation-state and the case of Western Europe. Daedalus 95: 826-915.

Hoffmann, Stanley. 1989. The European community and 1992. Foreign Affairs 68: 27-47.

Hooghe, Lisesbet, Tobias Lenz, and Gary Marks. 2019. A theory of international organization. Oxford: Oxford University Press.

Hull, C., and R.A.W. Rhodes. 1977. Intergovernmental relations in the European community. Aldershot: Gower.

Hurd, Ian. 2011. International organizations. Politics, law, practice. Cambridge: Cambridge University Press.

Joerges, Christian. 2001. Deliberative supranationalism-A defense. European Integration online Articles (EIoP) 5.

Jupille, Joseph, Walter Mattli, and Duncan Snidal. 2013. Institutional choice and global commerce. Cambridge: Cambridge University Press.

Keohane, Robert O., and S. JospehNye. 1977. Power and interdependence. Boston: Little, Brown.

Koremenos, Barbara, Charles Lipson, and Duncan Snidal. 2001. The rational design of international institutions. International Organization 55: 761-799.

Kratochwil, Friedrich, and John G. Ruggie. 1986. International organization: A state of the art on an art of the state. International Organization 40: 753-775.

Lebow, Richard N., and Thomas Risse-Kappen, eds. 1995. International relations theory and the end of the cold war. New York: Columbia University Press.

Lenz, Tobias, Jeanine Bezuijen, Liesbet Hooghe, and Gary Marks. 2015. Patterns of international organization: Task specific vs. general purpose. Politische Vierteljahresschrift 49: 107-132.

Lodge, Juliet E. 1998. Intergovernmental conferences and european integration: Negotiating the Amsterdam treaty. International Negotiation. A Journal of Theory and Practice 3: 345-362.

Long, J. Scott., and Jeremy Freese. 2005. Regression models for categorical dependent variables using stata. London: Stata Press.

Lowi, Theodore J. 1963. Toward functionalism in political science: The case of innnovationin party systems. The American Political Science Review 57: 570-583.

Malamud, Andrés, and Clarissa Dri. 2013. Spillover effects and supranational parliaments: The case of MERCOSUR. Journal of Iberian and Latin American Research 19: 224-238.

Mansfield, Edward, and Helen Milner. 1999. The new wave of regionalism. International Organization 53: 589-627.

Marshall, Monty G., Keith Jaggers, and Ted Robert Gurr. 2017. Polity IV project. Political regime characteristics and transitions, 1800-2016. Vienna: Center for Systemic Peace.

Mearsheimer, John. 1990. Back to the future: Instability in Europe after the cold war. International Security 15: 5-56.

Moravcsik, Andrew. 1993. Preferences and power in the European community: A liberal intergovernmental approach. Journal of Common Market Studies 31: 473-524.

Moravcsik, Andrew. 1997. Taking preferences seriously: A liberal theory of international politics. International Organization 51: 513-553.

Moravcsik, Andrew. 1998. The choice for Europe. Social purpose and state power from Messina to Maastricht. Ithaca, New York: Cornell University Press.

Mutimer, David. 1989. 1992 and the political integration of Europe: Neofunctionalism reconsidered. Journal of European Integration 13: 75-101. 
Panke, Diana. 2020. Regional cooperation through the lenses of states: Why do states nurture regional integration? Review of International Organizations 15 (2): 475-504.

Panke, Diana, and Sören. Stapel. 2018. Exploring overlapping regionalism. Journal of International Relations and Development 21 (3): 635-662.

Panke, Diana, Stefan Lang, and Anke Wiedemann. 2018. Regional actors in multilateral negotiations. Active and successful? London: ECPR Press.

Panke, Diana, Stapel Sören, and Anna Starkmann. 2020. Comparing regional organizations. Global dynamics and regional particularities. Bristol: Bristol University Press.

Pollack, Mark A. 1998. The engines of integration? Supranational autonomy and influence in the European Union. In European integration and supranational governance, ed. Wayne Sandholtz and Alec Stone Sweet. Oxford: Oxford University Press.

Puchala, Donald J. 1999. Institutionalism, intergovernmentalism and European integration: A review article. Journal of Common Market Studies 37: 317-331.

Ruppel, Oliver C., and Francois X. Bangamwabo. 2008. The SADC Tribunal: A legal analysis of its mandate and role in regional integration. In Monitoring regional integration in Southern Africa yearbook, ed. Anton Bösl, Willie Breytenbach, Trudi Hartzenberg, Colin McCarthy, and Klaus Schade, 179-220. Stellenbosch: Trade Law Centre for Southern Africa \& Konrad Adenauer Stiftung.

Sandholtz, Wayne. 1998. The emergence of supranational telecommunications regime. In European integration and supranational governance, ed. Wayne Sandholtz and Alec Stone Sweet, 134-163. Oxford: Oxford University Press.

Sandholtz, Wayne, and Alec Stone Sweet, eds. 1998. European integration and supranational governance. Oxford: Oxford University Press.

Slapin, Jonathan B. 2008. Bargaining power at Europe's intergovernmental conferences: Testing institutional and intergovernmental theories. International Organization 62: 131-162.

Söderbaum, Fredrik, ed. 2004. The political economy of regionalism. Basingstoke: Palgrave Mamillian.

Stone Sweet, Alec. 1999. Judicialization and the construction of governance. Comparative Political Studies 32: 147-184.

Stone Sweet, Alec. 2000. Governing with judges: Constitutional politics in Europe. Oxford: Oxford University Press.

Stone Sweet, Alec, and Wayne Sandholtz. 1997. European integration and supranational governance. Journal of European Public Policy 4: 297-317.

Stone Sweet, Alec, and Thomas Brunell. 1998. The European court and the national courts: A statistical analysis of preliminary references. Journal of European Public Policy 5: 66-97.

Stone Sweet, Alec, and Wayne Sandholtz. 1998. European integration and supranational governance. Oxford: Oxford University Press.

Stone Sweet, Alec, Wayne, Sandholtz, and Neil Fliegstein, eds. 2001. The institutionalization of Europe. Oxford: Oxford University Press.

Sunkel, Osvaldo, and András Inotai. 2016. Globalism and the new regionalism. New York: Springer.

Tallberg, Jonas. 2006. Leadership and negotiation in the European union. Cambridge: Cambridge University Press.

Telò, Mario, ed. 2001. European union and new regionalism: Regional actors and global governance in a post-hegemonic era. Aldershot: Ashgate.

Teorell, Jan, Stefan Dahlberg, Sören. Holmberg, Bo. Rothstein, Natalia Alvarado Pachon, and Richard Svensson. 2018. The quality of government standard dataset. Gothenburg: University of Gothenburg, The Quality of Government Institute.

Tranholm-Mikkelsen, Jeppe. 1991. Neo-functionalism: Obstinate or obsolete? A reappraisal in the light of the new dynamics in the EC. Millennium 20: 1-22.

Warleigh, Alex, and Ben Rosamond. 2010. Across the EU-studies-new regionalism frontier: Invitation to dialogue. Journal of Common Market Studies 48: 993-1013.

Weiler, Joseph H. H. 1981. The community system: The dual character of supranationalism. Yearbook of European Law 1: 268-306.

Publisher's Note Springer Nature remains neutral with regard to jurisdictional claims in published maps and institutional affiliations. 
Diana Panke is Professor of Political Science with a Chair in 'Multi-Level Governance' at the University of Freiburg. Her research interests include comparative regionalism, institutional design of international organizations, international negotiations, multilateral diplomacy, international norms, small states in international affairs, governance beyond the nation state, European Union politics as well as compliance and legalization. In these fields, she has published eight monographs (amongst them BUP, MUP, ECPR Press, Sage) and more than 50 peer-reviewed journal articles (in outlets including RIO, BJPIR, EJIR, IPSR, CPS, IP, IR, JCMS, or JEPP).

Anna Starkmann is a research associate and lecturer at the Chair in 'Multi-Level Governance', Department of Political Science, University of Freiburg. She graduated with a B.A. in European Studies from the University of Passau and an M.A. in Political Science from the University of Heidelberg. Her research interests include comparative regionalism, international and regional environmental and climate governance, and European Union climate governance. She has co-authored the book "Comparing Regional Organizations" (BUP) and published her work in the Journal of Common Market Studies and Journal of Contemporary European Studies. 